\title{
Omeprazole in the treatment of erosive oesophagitis refractory to high dose cimetidine and ranitidine
}

\author{
K D Bardhan, Pamela Morris, Mary Thompson, D S Dhande, R F C Hinchliffe, R B Jones, \\ M J Daly, N J H Carroll
}

\begin{abstract}
Forty five patients with refractory oesophagitis, defined as persisting erosive changes or ulceration despite a minimum of three months' treatment with cimetidine $3.2 \mathrm{~g}$ daily or ranitidine $0.9 \mathrm{~g}$ daily, were treated in an open trial with omeprazole $\mathbf{4 0} \mathrm{mg}$ daily for up to eight weeks. Endoscopically defined healing was observed in $73 \%$ of patients after four weeks' treatment and in $91 \%$ after eight weeks' treatment. Symptoms were completely relieved in $60 \%$ of patients, improved in $34 \%$, unchanged in $4 \%$, and worsened in $2 \%$. After healing patients returned to maintenance treatment with cimetidine 1.6-3.2 $\mathrm{g}$ daily, depending on the severity of their illness before treatment with omeprazole. By six months and 12 months only $55 \%$ and $33 \%$ of patients respectively were still in remission. This study suggests that when erosive oesophagitis is refractory to treatment with high dose cimetidine or ranitidine, treatment with omeprazole $40 \mathrm{mg}$ daily for up to eight weeks is effective in inducing healing and relieving symptoms.
\end{abstract}

The $\mathrm{H}_{2}$ receptor antagonists are less effective in the treatment of reflux oesophagitis than in peptic ulcer disease. Despite relieving symptoms of gastro-oesophageal reflux, these agents are often found to be ineffective in healing the erosive or ulcerative lesions in the oesophagus. ${ }^{1-3}$ Patients whose oesophagitis has failed to heal on such treatment are often considered for antireflux surgery. It is difficult, however, to manage patients who do not respond adequately to high doses of $\mathrm{H}_{2}$ receptor antagonists when their age or general condition makes elective surgery hazardous or they refuse operation.

It has been our practice to use cimetidine $1.6 \mathrm{~g}$ or $2 \mathrm{~g}$ daily routinely for the management of patients with erosive oesophagitis. Since 1984 we have used cimetidine $3 \cdot 2 \mathrm{~g}$ daily when the lower dose proved ineffective; ranitidine $0.9 \mathrm{~g}$ daily was used if patients were unable to tolerate high doses of cimetidine. At that time, early studies (in duodenal ulcer patients) had shown that omeprazole $40 \mathrm{mg}$ daily produced a profound reduction in acidity throughout the 24 hours, whereas increasing the dose of cimetidine had no greater effect on acid suppression. ${ }^{+6}$ It was on the assumption of greater acid inhibition that in early 1985 we treated our first few patients with omeprazole $40 \mathrm{mg}$ daily when their oesophagitis failed to heal with cimetidine $3 \cdot 2 \mathrm{~g}$ daily given for at least three months - that is, they had refractory disease. The results were sufficiently encouraging for us to treat more patients in a formal open study to assess healing rates, symptom relief, safety, and the outcome when patients whose oesophagitis had healed were subsequently maintained on high doses of cimetidine or ranitidine.

\section{Patients and methods}

\section{DEFINITION}

Refractory erosive oesophagitis was defined as the persistence of endoscopically proved erosions or ulceration, irrespective of symptoms, despite a minimum of three months of treatment with cimetidine $3.2 \mathrm{~g}$ daily $(800 \mathrm{mg}$ four times daily) or ranitidine $0.9 \mathrm{~g}$ daily $(300 \mathrm{mg}$ three times daily).

Healing was defined as a return to a normal oesophageal mucosa (grade 0 ) or one that was only mildly congested (grade 1 ).

\section{DESIGN OF STUDY}

Of necessity the study was an open one because omeprazole was supplied strictly for compassionate use in patients with intractable oesophagitis which had failed to heal with high doses of cimetidine and ranitidine. Patients with refractory erosive oesophagitis were treated with omeprazole $40 \mathrm{mg}$ (two $\times 20 \mathrm{mg}$ capsules), taken each morning for four weeks. If the erosive changes persisted treatment was extended for a further four weeks. Treatment was started within three days of the baseline endoscopy, and the examination was repeated at four weeks and again at eight weeks in patients not healed at four weeks. At each visit an assessment was made of symptoms and adverse events and blood was taken for routine laboratory studies. The symptom assessment was made by asking specifically about heartburn, epigastric pain, regurgitation, and dysphagia. In addition to the above a global score was used, anticipating that many of these elderly patients (half of the 45 patients were over 65 years) would not be able to give an accurate assessment of the separate symptoms. This score was determined as the most severe of the individual symptom assessments and graded as severe, moderate, mild, or none.

FOLLOW UP

After healing patients were put back onto maintenance treatment with cimetidine $1.6 \mathrm{~g}$ or $2 \mathrm{~g}$ daily. A higher maintenance dose (cimetidine $3.2 \mathrm{~g}$ daily or ranitidine $0.6 \mathrm{~g}$ daily if the former caused side effects) was used in the elderly or in those with a long history of troublesome oesophagitis. Clinical and endoscopic assessment was
Astra Clinical Research Unit, Edinburgh N J H Carrol Correspondence to: Dr K D Bardhan. Accepted for publication 25 September 1989 
made at six monthly intervals if symptoms were only mild or absent, or earlier if troublesome symptoms recurred.

\section{STATISTICAL ANALYSIS}

Correlation between symptoms and endoscopic appearances was performed using the McNemar test for equality of correlated proportions. ${ }^{7}$

\section{ETHICAL CONSIDERATIONS}

This study was approved by Rotherham District General Hospital Ethics Committee, and each patient gave written informed consent.

\section{GRADING OF OESOPHAGITIS}

The oesophagitis was graded 0 to 4 , according to a standard international system. ${ }^{8}$ Grade 0 : normal mucosa; grade 1: erythema or diffusely red mucosa and oedema causing accentuated folds; grade 2: aphthae with red halo extending from the oesophagogastric junction upwards in relation to the folds; grade 3: inflammatory and ulcerative changes extending around the entire lumen but without stenosis; grade 4: grade 3 plus ulceration, rigidity due to scarring, or stenosis, or Barrett's ulcer.

\section{Results}

Forty five patients who satisfied the entry criteria were treated. A further eight patients were unable to complete the minimum of three months' treatment with cimetidine $3 \cdot 2 \mathrm{~g}$ daily (or with ranitidine $0.9 \mathrm{~g}$ daily) due to the severity of their symptoms. They, too, were treated with omeprazole using the same protocol but their results are shown separately.

Of the 45 patients treated, 27 were 65 years or older with the majority having had longstanding symptoms (median 10 years). Their demographic features are shown in Table I.

TABLE I Demographic features of the 45 patients

\begin{tabular}{ll}
\hline Age (years) (mean (range)) & $63 \cdot 7(28-85)$ \\
Duration of symptoms (years) (median (range)) & $10(1-44)$ \\
Male/female & $24 / 21$ \\
Smokers $(n=44)^{\star}$ & $13(30 \%)$ \\
Drinkers $(n=44) \dagger$ & $20(46 \%)$ \\
Taking non-steroidal anti-inflammatory drugs & \\
$(n=44) \ddagger$ & $4(91 \%)$ \\
Obese $(n=38)$ & $20(53 \%)$
\end{tabular}

* Seven smoked $<10$ cigarettes/day, four smoked between 10 and 20 cigarettes/day, and the remaining two smoked $>20$ cigarettes/

day.

+13 drank up to 14 units, seven up to 30 units weekly. ( 1 unit $=$ on measure of spirit, or half a pint of beer, or one glass of sherry, or one glass of wine.)

$\ddagger$ Three used these drugs occasionally, and one used them regularly.

TABLE II Cumulative healing of oesophagitis as assessed by endoscopy. Figures are numbers (percentages)

\begin{tabular}{lcc}
\hline Result & $\begin{array}{c}\text { Week 4 } \\
(n=45)\end{array}$ & $\begin{array}{c}\text { Week 8 } \\
(n=45)\end{array}$ \\
\hline Healed: & $33(73)$ & $41(91)$ \\
Grade 0 (normal) & $18(40)$ & $22(49)$ \\
Grade l (mild congestion) & $15(33)$ & $19(42)$ \\
Improved (by $\geqslant$ one grade) & $2(4)$ & $0(0)$ \\
Unchanged & $8(18)$ & $4(9)$ \\
Worsened & $1(2)$ & $0(0)$ \\
Unknown & $1(2)^{\star}$ & $0(0)$ \\
\hline
\end{tabular}

^This patient did not have endoscopy at week 4 but was grade 0 at week 8 .
The median length of cimetidine treatment before omeprazole treatment was 23.0 months (range 3-120 months); cimetidine $1.6 \mathrm{~g}$ daily was used for a median of 10.0 months (range 0-73 months), $2 \mathrm{~g}$ for $7 \cdot 5$ months (range $0-51$ months), and $3.2 \mathrm{~g}$ for 4.0 months (range 3-26 months). Three patients were treated with ranitidine $0.9 \mathrm{~g}$ daily, which was considered equivalent to cimetidine $3 \cdot 2 \mathrm{~g}$ daily.

HEALING (Table II)

Thirty three patients received omeprazole treatment for four weeks only, the remainder for eight weeks. Healing (return to grade 0 or grade 1) occurred in $73 \%(n=33)$ of patients after four weeks' treatment; after eight weeks the cumulative healing rate was $91 \%(n=41)$. No patient had any final worsening of endoscopic appearance, although four $(\mathbf{9 \%})$ showed no improvement by eight weeks and one patient worsened by one grade at four weeks before healing at eight weeks. Healing to normal oesophageal mucosa that is, endoscopic grade 0 - was achieved by $40 \%(n=18)$ and $49 \%(n=22)$ by four and eight weeks respectively. In addition, a further $5 \%$ $(n=2)$ showed improvement by one grade or more but were still unhealed at four weeks; however, their disease had healed by eight weeks.

Thirteen patients had grade 4 oesophagitis when entering the study. Of these, four had stricture, one had Barrett's oesophagus, and one had both. The remainder had ulceration of the oesophagus without stricture or Barrett's oesophagus. Healing was greatest in patients with less severe oesophagitis, occurring (at four or eight weeks) in 23 of 23 patients with initial grade 2 disease, in nine of nine patients with initial grade 3 oesophagitis, and in nine of 13 who were of grade 4 at entry.

Thirteen patients had an oesophageal stricture before treatment - that is, the $11 \mathrm{~mm}$ diameter Olympus Q-10 endoscope tip would not pass through and stricture dilatation was required using bougies. After eight weeks' treatment with omeprazole only three patients had a residual stricture, which did not need dilatation.

\section{RELIEF OF SYMPTOMS (Table III)}

Of the 44 patients assessed clinically at four weeks, 26 had complete relief, with their global symptom score returning to zero, 15 had improved, three were unchanged, and none had worsened. Twelve patients were assessed after eight weeks of treatment when six patients had complete symptom relief, three were improved, two were unchanged, and one had worsened. Assessment of the $\mathbf{4 5}$ patients at the completion of their treatment showed $27(60 \%)$ had complete

TABLE III Global symptoms in patients before and during omeprazole treatment

\begin{tabular}{llll}
\hline & $\begin{array}{l}\text { At start } \\
(n=45)\end{array}$ & $\begin{array}{l}\text { At 4 weeks } \\
(n=44)\end{array}$ & $\begin{array}{l}\text { At 8 weeks } \\
(n=12)\end{array}$ \\
\hline None & 4 & 26 & 6 \\
Mild & 11 & 16 & 5 \\
Moderate & 11 & 2 & 1 \\
Severe & 19 & 0 & 0 \\
\hline
\end{tabular}


TABLE IV Number of patients with heartburn, epigastric pain, regurgitation, and dysphagia before and during omeprazole treatment (percentages in parentheses)

\begin{tabular}{llll}
\hline & Day 0 & Day 29 & Day 57 \\
\hline Heartburn: & & & \\
No. & 45 & 44 & 12 \\
None & $14(31)$ & $36(82)$ & $8(67)$ \\
Mild & 14 & 7 & 3 \\
Moderate & 9 & 0 & 1 \\
Severe & 8 & 1 & 0 \\
Epigastric pain: & & 35 & 9 \\
No. & 36 & $31(88)$ & $7(78)$ \\
None & $12(33)$ & 4 & 1 \\
Mild & 15 & 0 & 1 \\
Moderate & 6 & 0 & 0 \\
Severe & 3 & 43 & 12 \\
Regurgitation: & 44 & $37(86)$ & $9(75)$ \\
No. & $14(32)$ & 4 & 3 \\
None & 16 & 1 & 0 \\
Mild & 6 & 1 & 0 \\
Moderate & 8 & 43 & 12 \\
Severe & & $35(81)$ & $9(75)$ \\
Dysphagia: & 44 & 6 & 3 \\
No. & $23(52)$ & 1 & 0 \\
None & 10 & 1 & 0 \\
Mild & 5 & & \\
Moderate & 6 & & \\
Severe & &
\end{tabular}

relief, 15 (34\%) had improved global symptom scores, two (4\%) were unchanged, and one (2\%) had worsened. Table IV gives the separate symptom scores for heartburn, epigastric pain, regurgitation, and dysphagia.

\section{RELATION BETWEEN ENDOSCOPIC \\ APPEARANCES AND SYMPTOMS}

The separate symptom score assessments were compared in patients who had healed at day 29 and day 57 with the corresponding symptom scores at entry to the study. There was a significant association between symptom score at entry and at day 29 (Table V) in patients who had healed for heartburn, epigastric pain, regurgitation, and dysphagia $(\mathrm{p}=0.0001, \mathrm{p}=0.0000, \mathrm{p}=$ 0.0000 , and $p=0.001$ respectively). There was no significant correlation between any of the symptoms assessed for patients healing at day 57 .

\section{ADVERSE EVENTS}

Nine patients had adverse events on treatment. These were mild in five (bloating, rash, increase in usual dizziness, itching, constipation), moderate in two (dizziness and headache, nausea with tiredness and fainting), and severe in one (headache for two hours). None were serious enough to require discontinuing treatment. None could definitely be attributed to omeprazole.

TABLE V Comparison of numbers of patients with healed and patients with active oesophagitis at day 29 with or without symptoms

\begin{tabular}{|c|c|c|c|c|c|c|}
\hline & \multirow{2}{*}{\multicolumn{2}{|c|}{ At entry }} & \multicolumn{4}{|c|}{ At day 29} \\
\hline & & & \multirow{2}{*}{\multicolumn{2}{|c|}{$\begin{array}{l}\text { Oesophagitis present } \\
\text { Symptoms }\end{array}$}} & \multirow{2}{*}{\multicolumn{2}{|c|}{$\begin{array}{l}\text { Oesophagitis healed } \\
\text { Symptoms }\end{array}$}} \\
\hline & \multicolumn{2}{|c|}{ Symptoms } & & & & \\
\hline & Present & Absent & Present & Absent & Present & Absent \\
\hline $\begin{array}{l}\text { Heartburn } \\
\text { Epigastric pain } \\
\text { Regurgitation } \\
\text { Dysphagia }\end{array}$ & $\begin{array}{l}31 \\
24 \\
30 \\
21\end{array}$ & $\begin{array}{l}14 \\
12 \\
14 \\
23\end{array}$ & $\begin{array}{l}1 \\
1 \\
1 \\
4\end{array}$ & $\begin{array}{r}11 \\
7 \\
11 \\
7\end{array}$ & $\begin{array}{l}6 \\
2 \\
5 \\
4\end{array}$ & $\begin{array}{l}27^{\star} \\
25^{\star \star} \\
27^{\star \star \star \star} \\
28^{\star \star \star \star}\end{array}$ \\
\hline
\end{tabular}

Significance of correlation between healing at day 29 and change in symptom score: ${ }^{\star} \mathrm{p}=0.0001$; $\star^{\star \star} p=0.0000 ; \star \star \star p=0.0000 ; \star \star \star \star p=0.001$.

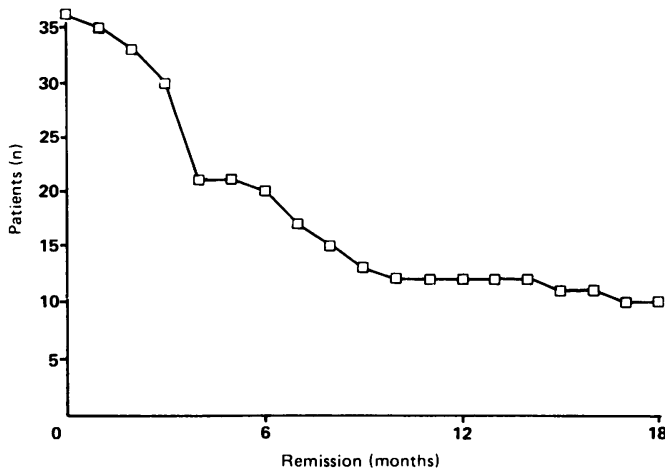

Number of patients in remission while receiving cimetidine $(1 \cdot 6 \mathrm{~g}-3 \cdot 2 \mathrm{~g})$ after healing of oesophagitis with omeprazole (40 mg).

HAEMATOLOGY AND BIOCHEMISTRY

Several laboratory results were outside the normal range before patients started treatment with omeprazole - for example, mild anaemia. But no clinically important new abnormalities were observed during omeprazole treatment.

\section{OUTCOME OF CIMETIDINE MAINTENANCE TREATMENT AFTER HEALING (Figure)}

Of 45 patients completing omeprazole treatment four were still unhealed. Thirty eight of the remaining 41 patients whose oesophagitis had healed went on to daily maintenance treatment with cimetidine: 15 with $1.6 \mathrm{~g}$, five with $2 \mathrm{~g}$, and 16 with $3.2 \mathrm{~g}$; the other two patients went on to maintenance treatment with ranitidine $0.6 \mathrm{~g}$ daily. One of these patients was lost to follow up and another was in remission after two months in 1989. Given the results of the remaining patients $(n=36)$, the proportion of patients in endoscopic remission was: at three months $83 \%$, at six months $55 \%$, at nine months $36 \%$, at 12 months $33 \%$, and at 18 months $27 \%$.

This group included one patient who had a symptomatic relapse only (endoscopy grade 1) after a month taking cimetidine $1.6 \mathrm{~g}$, and one patient on successful maintenance treatment with cimetidine $3 \cdot 2 \mathrm{~g}$ for nine months died three months later from ischaemic heart disease.

\section{SUBGROUP OF PATIENTS UNABLE TO}

COMPLETE CIMETIDINE $3 \cdot 2$ G DAILY FOR

AT LEAST THREE MONTHS BEFORE

OMEPRAZOLE TREATMENT

Healing occurred in all eight patients taking omeprazole, seven by four weeks and one by eight weeks. Seven patients then went on to maintenance treatment with cimetidine: two with $1.6 \mathrm{~g}$, four with $2 \mathrm{~g}$, and one with $3.2 \mathrm{~g}$. After six months in remission one patient died from the complications of pre-existing systemic sclerosis and the remaining six patients relapsed, the median time to recurrence (which was proved by endoscopy) being 6.2 months (range 3.2-10.75 months)

Combining the data from these eight patients with the main group of 45 patients for intention to treat analysis, the healing rate at four weeks was $40 / 53(75 \%)$, and at eight weeks $49 / 53(92 \%)$. Relapse on return to cimetidine and ranitidine maintenance treatment was $76 \%$ within 18 
months (median 3.6 months; range 0.8-16 months).

\section{Discussion}

We have observed that omeprazole $40 \mathrm{mg}$ daily is effective in managing erosive oesophagitis that is refractory to high dose treatment with cimetidine $(3.2 \mathrm{~g}$ daily) or ranitidine $(0.9 \mathrm{~g}$ daily). Towards the end of our investigations preliminary reports ${ }^{9-16}$ and two full reports ${ }^{17} 18$ became available showing the superiority of omeprazole 20-60 mg daily compared with standard ranitidine treatment ( $300 \mathrm{mg}$ daily) in healing erosive oesophagitis. The results of our open study show that omeprazole is also effective in controlling oesophagitis that is refractory to high doses of $\mathrm{H}_{2}$ receptor antagonists. After up to eight weeks' treatment healing and symptom relief occurred in $91 \%$ of patients, with $49 \%$ of patients having completely normal mucosa. Of 13 patients who had oesophageal stricture before treatment, only three had a residual stricture after taking omeprazole for eight weeks. The aggressive nature of their erosive oesophagitis is reflected by the fact that the disease had failed to come under control despite prolonged cimetidine treatment and that after healing with omeprazole and subsequent maintenance treatment with high $(1.6 \mathrm{~g}$ or $2 \mathrm{~g}$ ) or very high daily doses $(3.2 \mathrm{~g})$ of cimetidine or ranitidine $(0.6 \mathrm{~g})$ relapse occurred in $73 \%$ of patients by 18 months and in almost half the patients in only six months. Our data do not allow us to draw conclusions on whether the $3.2 \mathrm{~g}$ dose of cimetidine is more effective than lower doses in maintenance treatmeni, for the number of patients was small and the patients with most severe disease were preferentially put on the higher dose.

The refractoriness of the oesophagitis in our patients cannot be explained by consumption of non-steroidal anti-inflammatory drugs. Although the use of these drugs has been associated with serious oesophagitis and stricture formation, ${ }^{18}{ }^{19}$ in the present study only four of 44 patients took these drugs and only one took them regularly.

Though a few patients had adverse events, none was bad enough to warrant discontinuing treatment and in none was the drug believed to be causally related.

The difference between cimetidine and omeprazole in the ability to control the erosive oesophagitis in patients is most likely due to the different mechanisms of action in each and hence different levels of efficacy as antisecretory agents. Cimetidine inhibits gastric acid secretion through an action at the histamine $\mathrm{H}_{2}$ receptor of the parietal cell whereas omeprazole acts at the proton pump, which is the final secretory step, resulting in effective antagonism of all secretory stimuli. It is known that a daily dose of cimetidine $2.4 \mathrm{~g}$ produces marked inhibition of gastric acidity in healthy volunteers. ${ }^{20}$ In refractory duodenal ulcer patients studied at Rotherham, however, doubling or trebling the dose of cimetidine from $1 \mathrm{~g}$ to $2 \mathrm{~g}$ or $3 \mathrm{~g}$ daily did not produce appreciable further improvement in acid inhibition. ${ }^{+}$High doses of ranitidine (300 $\mathrm{mg}$ twice daily) have also been found to heal oesophagitis in only $50 \%$ of patients after a six week course of treatment; those not healed had no reduction in acid reflux." Since omeprazole inhibits the final acid secretory step it is probable that it causes more profound acid inhibition than even very high doses of cimetidine or ranitidine, the reduction being sufficiently great to allow refractory oesophagitis to heal.

In studies of oesophageal $\mathrm{pH}$ monitoring, omeprazole at doses of $20 \mathrm{mg}, 40 \mathrm{mg},{ }^{, 2}$ and 60 $\mathrm{mg}^{23}$ daily has been shown to markedly reduce the 24 hour acidity of the oesophageal lumen." In contrast, ranitidine $150 \mathrm{mg}$ daily has been found to be without effect. ${ }^{23}$ Omeprazole does not directly prevent reflux of the gastric contents since it has been shown to have no effect on lower oesophageal sphincter pressure. ${ }^{2425}$ The reduced 24 hour intraoesophageal acidity must therefore be due to lowering of the acid concentration in the refluxed gastric contents and of the gastric secretory volume.

For ethical reasons this study could not be performed as a comparative trial since patients could not be randomised to the $\mathrm{H}_{2}$ receptor blocking treatment which had already been shown to be ineffective for them. The results of our study are similar to those in preliminary reports $^{26-29}$ which indicated that omeprazole was effective in healing oesophagitis resistant to standard or higher doses of $\mathrm{H}_{2}$ receptor antagonists. The present study shows clearly that the high healing rates which can be obtained with omeprazole in non-refractory disease can also be achieved in patients whose oesophagitis is refractory to very high doses of cimetidine or ranitidine, and is safe.

We are indebted to Miss Beverley Mason and Mrs Lorna Robertson for typing the manuscript, to Dr Andrew Roberts for data processing, to Mrs Margaret Gammie for drug dispensing, to our endoscopy staff for their continued help, and to the Rotherham Health Authority and Astra for their support.

1 Wesdorp E, Bartelsman J, Pape K, Dekker W, Tytgat GN Oral cimetidine in reflux esophagitis; a double-blind controlled trial. Gastroenterology 1978; 74: 821-4.

2 Wesdorp ICE, Dekker W, Klinkenberg-Knol EC. Treatment of reflux oesophagitis with ranitidine. Gut 1983; 24: 921-4.

3 Koelz HR, Hirchler R, Bretholz A, et al. Healing and relapse of reflux esophagitis during treatment with ranitidine.
Gastroenterology 1986; 91: 1198-205.

4 Bardhan KD. Refractory duodenal ulcer. Gut 1984; 25 : 711-7.

4 Bardhan KD. Refractory duodenal ulcer. Gut 1984; $25: 711-7$.
5 Naesdal J, Bodemar G, Walan A. Effect of omeprazole, a Naesdal J, Bodemar G, Walan A. Effect of omeprazole, a
substituted benzimidazole on $24 \mathrm{H}$ intragastric acidity in patients with peptic ulcer disease. Scand $\mathcal{f}$ Gastroenterol 1984; 19: 916-22.

6 Sharma BK, Walt RP, Pounder RE, et al. Optimal dose of oral omeprazole for maximal 24 hour decrease of intragastric acidity. Gut 1984; 25: 957-64.

Bradley JV. Distribution free statistical tests. Englewood Cliffs, NJ: Prentice Hall, 1968: 183.

8 Maratka $Z$. Terminology, definitions and diagnostic criteria in digestive endoscopy. Scand $\mathcal{F}$ Gastroenterol 1984; 19 (Suppl 103): 27.

9 Dammann HG, Blum AL, Lux G, et al. Omeprazole is superior to ranitidine in the treatment of reflux esophagitis [Abstract]. Gastroenterology 1986; 90: 1385.

10 Vantrappen G, Coenegrachts JL, Rutgeerts L, Schurmans P. Omeprazole $(40 \mathrm{mg})$ is superior to ranitidine in the short term treatment of ulcerative reflux esophagitis [Abstract] Gastroenterology 1987; 92: 1681

11 Hetzel DJ, Dent J, Reed W, et al. Healing of peptic esophagitis with omeprazole: a dose-response study [Abstract]. Gastroenterology 1987; 92: 1434 .

12 Hetzel DJ, Dent J, Reed W, Narielvala F, Mackinnon M, Laurence $B$. Healing and relapse of reflux oesophagitis after treatment with omeprazole $20 \mathrm{mg}$ or $40 \mathrm{mg}$ daily [Abstract]. Gut 1987; 28: A1376-7.

13 Zeitoun P, De Keranroue ND, Isal JP. Omeprazole versus ranitidine in erosive oesophagitis. Lancet 1987; ii: 621-2.

14 Whitehead R, Hetzel DJ, Dent J, Reed W, Narielvala F. Histological healing of peptic esophagitis with omeprazole [Abstract]. Gastroenterology 1987; 92: 1693.

15 Lundell L, Fausa O, Sandmark S. Omeprazole or ranitidine in the treatment of reflux oesophagitis - results from a double 
blind, randomised, Scandinavian multicentre study [Abstract]. Gut 1987; 28: A1375.

16 Brunner G, Harke U, Lamberts R, Creutzfeldt W. Uber die wirkung von omeprazol auf ranitidin-resistente ulcerationen im obren intestinaltrakt. (On the effect of omeprazole on esophageal, ventricular or duodenal ulcer resistant to ranitidine) [Abstract]. $Z$ Gastroenterol 1986; $24: 468$.

17 Klinkenberg-Knol EC, Jansen JMBJ, Festen HPM, Meuwissen SGM, Lamers CBHW. Double-blind multicentre comparison of omeprazole and ranitidine in the treatment of reflux oesophagitis. Lancet 1987; i: 349-51.

18 Havelund T, Laursen LS, Skoubo-KJristenien, et al. Omeprazole and ranitidine in treatment of reflux oesophagitis: double blind comparative trial. Br Med f 1988; 296: 89-92.

19 Heller SR, Fellows TW, Ogilvie AL, Atkinson M. Nonsteroidal anti-inflammatory drugs and benign oesophageal stricture. Br Med F 1982; 285: 167-8.

20 Kapur B, Mills JG, Glenny H, Burland WL, Lunt MJ Bardhan KD. Evaluation of large single night-time doses of cimetidine using continuous 24-hour ambulatory gastric $\mathrm{pH}$ cimetidine using continuous 24-hour ambula
monitoring [Abstract]. Gut 1985; 26: A557.

21 Robertson DA, Aldersley MA, Shepherd H, Lloyd RS, Smith CL. $\mathrm{H}_{2}$ antagonists in oesophagitis: can physiological $\mathrm{CL} . \mathrm{H}_{2}$ antagonists in oesophagitis: can physiological
studies predict the response? [Abstract]. Gut 1987; 28: studies

22 Pasqual JC, Hemery P, Bruley S, Galmiche JP. Comparison of the effects of two doses of omeprazole on 24-hour esophageal $\mathrm{pH}$ in gastroesophageal reflux disease [Abstract]. Gastroenterologv 1987; 92: 1567 .
23 Klinkenberg-Knol EC, Festen HPM, Meuwissen SGM Omeprazole compared to ranitidine in effect on 24-hour $\mathrm{pH}$ in the distal esophagus of patients with reflux esophagitis. A double-blind trial [Abstract]. Gastroenterology 1987; 92. 1471 .

24 Chakraborty TK, DeCaestecker JS, Pryde A, Heading RC. Effect of omeprazole on lower oesophageal function in Effect of omeprazole on lower oesophageal function in
normal subjects. Aliment Pharmacol Therap 1987; 1: 627-32.

25 Dent J, Heddle R. Dowton J, MacKinnon M, Toouli J, Lewi I. Omeprazole heals ulcerative peptic esophagitis [Abstract]. Gastroenterology 1984; 86: 1062 .

26 Fausa D, Aadland E, Lotveit T. Omeprazole in the treatmen of patients with severe erosive esophagitis resistant to treatment with $\mathrm{H}_{2}$-receptor antagonists [Abstract]. Scand $\mathfrak{F}$ Gastroenterol 1987; 122 (Suppl 135): 38

27 Fiasse R, Druez P, Descamps Ch, Lienard JC, Coppens JP, Dive $\mathrm{Ch}$. Omeprazole treatment of severe reflux esophagitis resistant to $\mathrm{H}_{2}$-receptor antagonists. International organization for statistical studies on diseases of the esophagus (OESO). 2nd International Polydisciplinary Congress. Paris, June 1987 (Abstract).

28 Klinkenberg-Knol EC, Meuwissen SGM. Is omeprazole effective in the treatment of patients with reflux esophagitis not responding to $\mathrm{H}_{2}$-receptor antagonists? [Abstract]. Gastroenterology

29 Klinkenberg-Knol EC, Jansen JBMJ, de Bruyne JW, et al. Long-term treatment with omeprazole in resistant reflux oesophagitis; effects on endoscopic healing and fasting serum gastrin levels [Abstract]. Gut 1987; 28: A1379. 